\title{
Obituary
}

\section{Thomas Wallace Bloxam BSc, PhD, DSc, FGS, FRIC (1926-2019)}

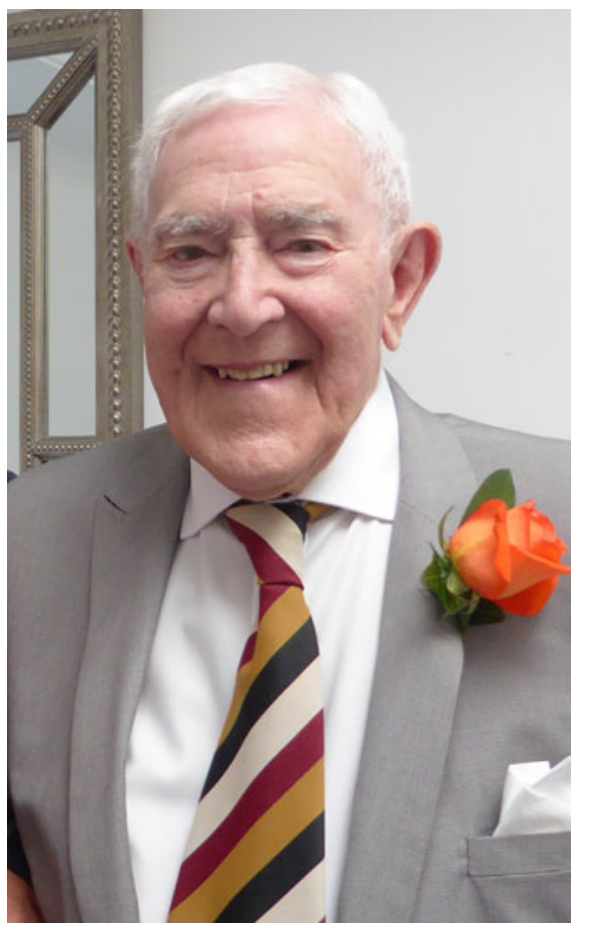

Born in Greenwich, London, on the 24th February, 1926, the family moved to Edinburgh in 1933 where Thomas Wallace Bloxam was educated at George Heriot's School. In 1943 he went to sea as a radio officer on Atlantic convoys and, with an ex-service grant, to Edinburgh University, graduating with First Class Honours in geology in 1951. He was also awarded a Vans-Dunlop Scholarship to further post-graduate research at the University of Glasgow where he was appointed Assistant Lecturer from 1951 to 1954 . Inspired by the teaching of Arthur Holmes at Edinburgh he was to develop broad geological interests.

His research at Glasgow was on the ophiolites, blueschists and related rocks of the Girvan-Ballantrae district in south-west Scotland where he was the first to recognise rodingite, hydrogrossular and pumpellyite in British ophiolites. In 1954 he was awarded a PhD, and a Commonwealth (Harkness) Fellowship to the United States at the University of Princeton and the University of California, Berkeley. Most of his time was spent at Berkeley under the guidance of Frank Turner where he mapped and described blueschists and associated ophiolites of the Coast Range around San Francisco and Angel Island. He noted the extensive occurrence of jadeite in metamorphosed Franciscan greywackes and suggested that load pressure, augmented by

Cite this article: Bloxam T.W. (2019) Obituary: Thomas Wallace Bloxam BSc, PhD, DSc, FGS, FRIC (1926-2019). Mineralogical Magazine 83, 319-319. https://doi.org/10.1180/ mgm.2019.22 deformation, was responsible. These areas subsequently turned out to be the low-temperature high-pressure subduction zones of later plate-tectonic theory.

He returned to the UK and was a Lecturer at the University of Southampton until 1957 when he left to take up a Lectureship at University College Swansea. Here, under the enthusiastic leadership of Frank Rhodes, he established geochemical facilities and a vigorous research group in both hard rock and sedimentary rocks, with particular reference to the Carboniferous of South Wales. Geochemical studies on Palaeozoic phosphatic shells and their environments formed a joint publication with Frank Rhodes (Rhodes and Bloxam, 1971). In 1961 he described stilpnomelane for the first time in Ordovician granophyres and tuffs from North Wales (Bloxam and Price, 1961) for which he proposed a low-grade metamorphic origin.

With a British Council Senior Award he visited the Vernadskiy Institute of Geochemistry, Moscow, in 1966 and in 1974 took extended leave to assist the University of Sierra Leone (Freetown) Department of Geology in setting-up geochemical facilities, supported by the Interuniversity Council. Student interchange and publication of research on heavy metals in laterites were to follow. He published several papers on analytical methods in geochemistry and was elected Fellow of the Royal Institute of Chemistry in 1974.

At Swansea the Girvan-Ballantrae research continued and the results were summarised in Igneous Rocks of the British Isles (Sutherland, 1982). In Pembrokeshire, where he had mapped as an undergraduate in 1950, Ordovician volcanic and volcaniclastic rocks around Fishguard were found to include subaqueously welded ash flows, recognised for the first time in South Wales (Lowman and Bloxam, 1981) and Late Precambrian bimodal volcanic rocks around St. David's, which contained welded ash flows, were considered to be ensialic back-arc in origin.

In 1982 he was awarded a DSc by the University of Glasgow on the basis of published work. He was External Examiner in geology at the Universities of Sierra Leone, Southampton and Bristol; Member of Council of the Mineralogical Society of Great Britain and Ireland (1963-1965) and a subeditor of Mineralogical Abstracts (1966-1988). He was an accomplished modern jazz pianist and electronics enthusiast. He died on the 23rd January 2019.

\section{References}

Lowman R.D.W. and Bloxam T.W. (1981) The petrology of the Lower Palaeozoic Fishguard Volcanic Group and associated rocks E of Fishguard, N Pembrokeshire (Dyfed), South Wales. Journal of the Geological Society, 138, 47-68.

Rhodes F.H.T. and Bloxam T.W. (1971) Phosphatic organisms in the Paleozoic and their evolutionary significance. Pp. 1485-1513 in: Phosphate in Fossils (E.L. Yochelson, Editor). Proceedings of the North American Paleontology Convention $\mathrm{K}$.

Sutherland D.S. (editor) (1982) Igneous Rocks of the British Isles. Wiley.

Bloxam T.W. and Price N.B. (1961) Stilpnomelane in North Wales. Nature, 190, 525-526. 